\title{
The Impacts of Globalization on Human Resource Development Management
}

\author{
Ali Gunawan ${ }^{1}$, Stephen Gregorius Kurnia ${ }^{2}$, Hasan Ghazali ${ }^{3}$ \\ ${ }^{1,2}$ Information Systems Department, School of Information Systems, Bina Nusantara \\ University, Jakarta, Indonesia 11480 \\ gunlee77@gmail.com \\ ${ }^{3}$ Communication Department, BINUS Graduate Program - Master of Strategic Marketing \\ Communication, Bina Nusantara University, Jakarta, Indonesia 11480 \\ hghazali@binus.edu
}

Received: November 17 $7^{\text {th }}$ 2018/ Accepted: March $6^{\text {th }}, 2019$

\begin{abstract}
The terms "Globalization" and "The Digital Era" are familiar words that sound in our ears which mean progress or development. The term globalization is a term that has links to increase interdependence among nations and people around the world through trade, investment, travel, popular culture and other forms of interaction so that the boundaries of a country become biased. Globalization can bring about changes in all areas such as culture, economy, social, politics, ideology and so on. On the one hand, globalization brings with its positive consequences and on the other hand also carries negative sides. The Digital Era supports the process of Globalization to make it easier to accomplish, which makes it all easy to communicate with anyone and anytime, accessing data and information easily and quickly wherever we are especially supported by the tools of modern softwares and hardwares. The Digital Era can also develop the capabilities of human resources must be able to adjust to use it. For human resources who are unable to compete will be replaced with more capable ones. However, currently Human Resources in Indonesia have not been fully encouraged to enter the Digital Era due to the constraints of several factors, such as the availability of infrastructure, the cost of digital is still inadequate when associated with the number of people with the level education and low technological understanding so they are accustomed to do jobs that do not require special skills. Here ther role of all groups, communities and governments, to further improve the skills of human resources so as to be able to improve the economy and welfare.
\end{abstract}

Keyword: Digital Era, Globalization, and Quality of Human Resources

\section{INTRODUCTION}

\section{Background}

Data from the Central Bureau of Statistics (BPS) noted that in March 2017 the population of Indonesia has reached 257,91 million people where the number of productive age population ranging from age 18 to 55 years old is 167.05 million people or about $65 \%$ of the total population. Where the number of unemployed has reached 7.02 million people from productive age or about $4.02 \%$ and every year has increased. In march 2017 the number of poor people, the population with per capita expenditure per month below the Poverty Line) in Indonesia reached 27.77 million people close to $10 \%$ of the total population. This is due to the low level of education in Indonesia. Data from the Central Bureau of Statistics can be seen from the table 1.0 below. 


\begin{tabular}{lcr}
\hline Education Level & $\%$ & Total $\%$ \\
\hline Not or not finished Elementary & $7.82 \%$ & $7.82 \%$ \\
\hline Finished Elementary & $36.26 \%$ & $44.09 \%$ \\
\hline Finished Junior High School & $22.62 \%$ & $66.71 \%$ \\
\hline Finisehed Senior High School & $26.05 \%$ & $92.77 \%$ \\
\hline Finished College & $7.23 \%$ & $100.00 \%$ \\
\hline \multicolumn{3}{c}{ Table 1.0 Education Level in Indonesia }
\end{tabular}

From the table above, it can be seen that college graduate is still below $10 \%$ and high school graduate or equivalent only 26.05\%. Based on data from the Education For All (EFA) Global Monitoring Report 2011: The Hidden Crisis, Armed Conflict and Education issued by the United Nations Educational, Scientific and Cultural Organization (UNESCO), launched in New York on Monday (1/3/2011), the education development index (EDI) based on the 2008 data is 0.934 . The value puts Indonesia in the $69^{\text {th }}$ Position of 127 countries in the world. In addition to the comparison information of Indonesian Workers abroad with Foreign Workers in Indonesia can be seen in Figure 1.0 below.

\begin{tabular}{|c|c|c|c|c|c|}
\hline \multirow{2}{*}{ No } & \multirow{2}{*}{ Marital Status } & \multicolumn{2}{|l|}{2015} & \multicolumn{2}{|l|}{2016} \\
\hline & & January - May & $\%$ & January - May & $\%$ \\
\hline 1 & Married & 66.826 & 55 & 50.541 & 52 \\
\hline 2 & Single & 45.499 & 38 & 40.058 & 41 \\
\hline 3 & Divorced & 8.640 & 7 & 6.750 & 7 \\
\hline & Total & 120.965 & 100 & 97.349 & 100 \\
\hline \multirow{2}{*}{ No } & \multirow{2}{*}{ Education } & 2015 & & 2016 & \\
\hline & & January - May & $\%$ & January - May & $\%$ \\
\hline 1 & Graduate & 11 & 0,01 & 7 & 0,01 \\
\hline 2 & Undergraduate & 674 & 0,56 & 521 & 0,54 \\
\hline 3 & Diploma & 2.378 & 1,97 & 1.134 & 1,16 \\
\hline 4 & Senior High School & 30.494 & 25,2 & 28.452 & 29,23 \\
\hline 5 & Junior High School & 44.937 & 37,15 & 39.421 & 40,49 \\
\hline \multirow[t]{2}{*}{6} & Elementary School & 42.471 & 35,11 & 27.814 & 28,57 \\
\hline & Total & 120.965 & 100 & 97.349 & 100 \\
\hline
\end{tabular}

Figure 1.0 above shows the percentage of Indonesian workers abroad with a minimum education of Bachelor no more than $1 \%$. So, it can be said that Indonesian workers who work non-skill or said rough workers reach almost $100 \%$. In contrast, according to the Minister of Manpower, M. Hanif Dhakiri based on data on IMTA (Foreign Workers Permit), foreign workers employed in Indonesia amount to about 70,000 people. The dominant occupation of Foreign Workers in Indonesia are professionals, directors, managers, advisors/consultants, commissioners, skilled technicians and supervisors in other words all works that uses the ability (skill).

\section{Problem Formulation}

Based on the above titles and backgrounds, there is an imbalance in distributing and accepting labors globally. With the abovemention reason, then the workforces in Indonesia have not been considered equivalent to the workforce abroad. The impact of this inequality is on the remuneration of Indonesian labor, the welfare of Indonesian workers, to the equality of skills and social recognition of Indonesian workers abroad. In summary, the problems encountered are as follows:

- Low level of education in Indonesia 
- The need to increase the role of human resources in Indonesia.

Writing Purposes

The purposes of this writing are:

- Providing an understanding of the importance of education to stakeholders in the field of education to improve the empowerment of human resources and economic improvement of the nation.

- Giving inputs to the government in order to foster education in accordance with the current generation that already has technological literacy.

\section{Writing Benefits}

As for the benefits of this writing are to increase readers' insights on youth understanding of technology and education, so as to direct education, environment and technology to work together to support the development of education. Another benefit of this article is giving additional references or other sources of useful knowledge in adding information to parents or educators.

\section{DEFINITION AND CONCEPT}

\section{Human Resources Management}

Suwatno dan Priansa stated that management is "Science and art manage the process of utilizing human resources and other resources effectively and efficiently to achieve a certain goal" [1]. Management consists of six elements (6M), namely: Men, Money, Method, Material, Machine, and Market. Human element (Men) developed into a field of management science called Human Resources Management (MSDM). Management that governs the human element. Human Resource Management is a management field that specializes in studying human relationships and roles in corporate organizations. The element of Human Resource Management is the human being who is the workforce of the company"

"Human always plays an active and dominant role in every organizational activity, because humans become planers, actors, and determinants of the realization of organizational goals. Such a goal can not be ralized without the active role of the employee however sophisticated the tools the company possesses. Sophisticated tools owned by the company are of no use to the company, if the employee's active role is excluded. Organizing employees is a difficult and complex thing, because they have thoughts, feelings, status, desires, and heterogeneous backgrounds brought into the organization so that employees can not be fully regulated and controlled such as arranging machines, capital, buildings, etc. However it must be governed by management theories that focus on regulating the role of human beings in realizing the optimal goals" [1].

The practice of human resource management relates to all aspects of how people work and are managed within the scope of the organization, where activities such as corporate social responsibility, reward management, employee relations, employee prosperity, health and safety, and the provision of services to employees is one of them [1].

Human Resources Management is one of the areas of general management covering aspects of planning, organizing, implementing and controlling. All of these processes are covered in production, marketing, finance, and personnel [2]. Therefore, Human Resources' role is considered increasingly important in achieving corporate goals so that experience and results of research in the field of Human Resources systematically collected in the so-called human resources management. The term management in human resource management means a collection of knowledge about how human resources should be managed.

Human resource management refers to policies, practices, and systems that affect employee behavior, attitudes, and performance. The concept of Human Resources Management is often reffered to as a form of human practices. [3] 
Human Resource Development

Human Resource Development can be defined as a set of systematic and planned activities designed by an organization to give its members the opportunity to learn the skills necessary to meet current and future job demands. In a broader sense, human resource development seeks to develop knowledge, experience, expertise, productivity, and employee satisfaction [1].

Human resource development is a strategic approach to investing in human resources [1]. Human resource development provides a framework for self-development, training programs and career advancements tailored to future organizational skills needs.

Human Resource development is a process to improve human resource capacity in helping the achievement of organizational goals (Build, 2012). According to Priansa (2014:146), the development of human resources can be understood as the preparation of individual employees to assume different or higher responsibilities within the organization. Development is usually associated with the improvement of intellectual or emotional skills needed to perform better jobs. Human resource management system, including training and development, career development, and programs and processes of organizational development [4].

According to some understanding of the experts above, it can be concluded that the development of human resources is an activity undertaken by the organization in order to improve the skills owned by employees, in order to meet the demands of changes and environmental developments that occur in the organization.

Competency Theory

As an individual characteristic attached to the someone's personality, competence will be seen in the way a person behaves in his workplace.

According to Spencer and Spencer (1993) in L Krisna (2014, 2) [5] suggests that competence can be sourced from five different types of sources:

1. Motives is something where one is consistently thinking so that he takes action. For example, a person with a consistent achievement motivation will develop goals that challenge him or her and take full responsibility for achieving that goal and expect feedback to improve.

2. Traits is characters that make a person behave or how someone responds to something in a certain way. For example self-confidence, self-control, stress or fortitude.

3. Self Concept is the attitude and values a person has. Attitudes and values are measured through the test to the respondent to know how the value a person has and what attracts it to someone doing something. For example someone who is considered worthy of leadership should have leadership behavior so that need for a test of leadership ability.

4. Knowledge is the information that a person has for a particular field. Knowledge is a complex competency but sometimes a score on a test of knowledge often fails to predict human resources performance because the score does not successfully measure what knowledge and expertise should be done in its work. The knowledge test measures the ability of the test participants to choose the most correct answer but can not see whether someone is doing the job based on the knowledge they have.

5. Skills is the ability of a person to perform a certain task both physically and mentally. For example a computer programmer makes a program related to Driver's License (SIM) of the human resource.

\section{RESEARCH METHODOLOGY}

Research methods used in this writing are as follows:

- Focus Group Discussion with primary and secondary education practitioners

- Methods of literature review through research journals related to the role of government in improving education in Indonesia, and other references related to the discussion of this paper. 
- Reading methods from educational writer's writings published in online media and printed media.

\section{RESULTS AND DISCUSSION}

The framework of thinking in employment discussions involving several constituents in the field of education and employment, including the ministry of basic education, ministry of religion, the ministry of labor, the ministry of youth and sports, and the ministry of research and technology together with the director of research and community service University Indonesia, is to be a top priority. It begins with good education and quality. Good education is quality, has relevance to the needs of the community and the world of work. Good education is holistic planned education, including learning methods, facilities and infrastructure and a good teacher.

In order to be able to compete in this globalization era, education standard in Indonesia must be improved. This has also been expressed by former Bank Indonesia Governor Darmin Nasution in order to face the implementation of the ASEAN Economic Community. The impact of globalization is a service sector perspective that requires skilled professionals. Efforts to improve the quality of human resources need to be planned jointly between academia, government and business actors, to determine the competence of workers, learning standards and efforts of standardization and certification conducted by the regulator, namely the government. President of the Republic of Indonesia, Joko Widodo in early August in front of observers of education in Bandung, also pay attention to the role of generation $\mathrm{Y}$ as a generation that can affect the market both political and economic in Indonesia. Generation $\mathrm{Y}$ is considered to have the impact of global change, so it should be anticipated to be able to support it. This has an effect on education, especially to form a department developed to be more specific to accommodate the change.

Minister of Higher Education and Technology, Nasir, has said that the keys to success in winning global competition are hard work and enthusiasm for learning [6]. This was stated at Diponegoro University which was also followed by Undip Rector, Vice Rector, Dean, Vice Dean and Semarang City Government. Minister Nasir also convey the era of global competition means the entry of the world community into all sectors of society activities in Indonesia. This could lead to a threat if the Indonesian does not have the competence to fill it. However, for universities, it is also an opportunity to dominate the ASEAN market if they have interests, talents and knowledge.

The minister of education and culture has also been preparing to undertake National Educational reforms at th conceptual and manajerial level. One of them is to prepare character formation at the elementary level of education, and to formulate the space for self-actualization of potential for advanced education, to discover the skills and skillfulness of high competition needed by the world of $21^{\text {st }}$ century. This is delivered in National Education Day 2017. Only characters of a strong and highly competitive ability capable bring Indonesia to stand upright among other advanced country in the future. In order to do so, there are programs being done; making the movement strengthening character education (KDP) and National Literacy Movement (GLN). In the field of formal education, revitalization of SMK to answer the problems of Indonesian with a long-term process.

While from the industry, the government's strategic plan is supporting the industry to face the MEA consists of strengthening Economic Competitiveness, I love Indonesia Programe, Strengthening SME Sector, Infrastructure Improvement, Improving the quality of human resources, institutional reform and governane The government realizes that the quality of human resources is very important, and the only way is through education. Therefore, the government also build educational facilities and infrastructure to provide quality education services. Improve the substance of the curriculum, and rehabilitate the classrooms and schools to provide comfort for students to learn and improve the quality of learning. 


\section{CONCLUSION}

Indonesia's potential in participating in the global market is enormous. With large population and the government's focus on improving the quality of human resources, Indonesia is considered a second country for future investment and business opportunities after China. However, the current obstacle to be solved are improving educational equity and increasing the role of industry in improving the quality of human resources. Vocational Education which is currently starting to run the government can be the beginning of the creation of good human resources competence and excellence. For the future, we can examine the effectiveness of the opening of vocational programs on the quality of human resource competencies supported by technology literacy, Indonesia will be able to take advantage and opportunity from the creation of Asian Free Market (MEA).

\section{References:}

[1] Suwatno dan Donni Juni Priansa. 2014. Manajemen SDM dalam Organisasi Publik dan Bisnis, Penerbit Bandung: Bandung

[2] Veithzal Rivai. 2014. Kepemimpinan Dan Perilaku Organisasi, ed. Keempat. Rajawali Pers, Jakarta.

[3] Noe, Raymond A., et. al. (2010). Human Resource Management, Gaining Competitive Advantage 3rd Edition.McGraw-Hill.

[4] Jon M. Werner, Randy L. DeSimone. Human Resource Development 6th Edition. 2011. International Student Edition.

[5] Spencer, Peter M., \& Signe M. Spencer. (1993). Competence at Work "Models for. Superior Performance". New York: Jhon Wiley \& Sons Inc.

[6] Nasir, "Visi Global untuk Menangkan Persaingan Dunia", 2013. Orasi Ilmiah Universitas Diponegoro Semarang. 